\title{
MUSIC IN HEALTHY AND \\ DISEASED BRAIN
}

\section{Aleksandra M. Pavlović 1,2 Dragan M. Pavlović $3,4,5$}

1. Faculty of Medicine, University of Belgrade, Belgrade, Serbia

2. Neurology Clinic, Clinical Centre of Serbia, Belgrade, Serbia

3. Faculty for special education and rehabilitation, University of Belgrade, Belgrade, Serbia

4. Faculty of Philosophy, Department of Psychology, University of Belgrade, Belgrade, Serbia

5. Antamedica Polyclinic, Belgrade, Serbia

UDK: 616.895.8-085

\section{Financial disclosure:}

This article is partially financed by the Ministry of Science, Republic of Serbia, Project No 175033 and 175022

\section{Summary}

Art and creativity originate in the brain and depend on normal brain functioning. Music is a multifacet phenomenon that exists as a universal heritage across all human societies and throughout the entire human history. There are numerous brain-based mechanisms involved in the cognitive processing of music, including music listening, performing, composing, reading, writing, as well as musical aesthetics and musical emotion. Music relates to many brain functions including perception, motor action, cognition, emotion, learning and memory. Various brain regions are associated with music processing and production, including the right anterior and posterior superior temporal lobe, the right inferior frontal cortex, the right prefrontal, bilateral premotor and bilateral parietal areas, the right anterior cerebellar lobe, language areas and limbic structures. In a diseased brain, after acquired brain injury, disorders in music perception or production have been described, although considered rare. Amusia or music-specific agnosia, a defective 
perception of music or its components is typically associated with temporal lobe lesions, and is more likely to occur with right-sided involvement. Etiology of acquired amusia comprise many diseases and conditions leading to brain injury, including traumatic brain injury, ischemic or hemorrhagic stroke, neoplasma, iatrogenic and epilepsy-related conditions, infections and degenerative diseases. Additionally, there are cases of congenital amusia, attributed to abnormality in neural networks for music, associated with structural variations in the frontal and temporal lobes.

Key words: music cognition, amusia, behavioral neurology, brain and music, brain injury

\section{INTRODUCTION}

"Where words fail, music speaks."

Hans Christian Andersen

Music is a multifacet phenomenon that has been universally present throughout human history and across all human populations ${ }^{[1]}$. Undoubtedly, music originates in our brain and normal brain functioning is required in order to perceive, analyze, enjoy and create music. The perception and performance of music is complex as it entails a variety of perceptual (listening), sensorimotor and praxic (playing an instrument), visual (reading a musical score), mnemonic (playing a piece from memory), as well as affective (emotional experience of music) processes ${ }^{[1]}$. Consequently, music offers amazing insights into complex brain organization and the variety of its functions. Furthermore, musical aptitude and the unique effects of musical training are fascinating when studying brain plasticity, documented in extensive research in the last decades.

Positron emission tomography (PET) and functional magnetic resonance imaging (fMRI) studies proved the activation of large cortical and subcortical cerebral areas while listening to pleasurable music ${ }^{[2]}$. There is evidence that in healthy subjects preferable music evokes emotions linked to heightened arousal, resulting in temporarily enhanced performance in many cognitive domains, 
with improvement in declarative memory, processing speed and reasoning skills in spatial problem solving ${ }^{[2]}$. Music therapy may offer benefits to patients with various clinical conditions including cardiovascular diseases, cancer pain, psychiatric disorders, traumatic or ischemic brain injury and dementia, although still not fully elucidated mechanisms $s^{[3]}$.

\section{AUDITORY CORTEX AND ITS CONNECTIONS}

"Music is a higher revelation than all wisdom and philosophy."

Ludwig van Beethoven

Primary auditory cortex. Cognitive neuroscience of music starts with basic functions of the auditory cortex. The primary auditory cortex (A1), which is idiotypic, is located in the temporal operculum, in the superior temporal gyrus (Brodmann's area 41 and part of 42) and is referred to as Heschl's gyrus. A1 receives direct point-to-point input from the ventral division of the medial geniculate complex (MGC) of the thalamus and contains a precise tonotopic map ${ }^{[4]}$. So the primary auditory cortex has a topographical map of the cochlea through the thalamus.

Inputs to auditory cortex. A major source of input to the auditory cortex is coming from the ventral division of the MGC in the thalamus, often referred to as the lemniscal pathway, transmitting strictly auditory information ${ }^{[5]}$. These neurons receive most of their ascending input from tonographically arranged neurons in the central nucleus of the inferior colliculus. In addition, there is important thalamic input coming from dorsal division of the MGC, often referred to as the paralemniscal or extralemniscal pathway. These pathways receive nontonotopic inputs from the inferior colliculus, exhibit less topographic organization, broader tuning, longer and more variable response latencies and tendencies to habituate to ongoing stimuli. The third main circuit is the medial MGC division that projects not only to auditory cortical areas but also to nonauditory cortical areas as well as to the amygdala. Additionally, other subcortical structures project to the auditory cortex, likely serving associative, learning and sensory integration purposes $^{[5]}$.

Functions of the auditory cortex. Some areas of the auditory cortex are specialized for processing combinations of frequencies, while others are specialized for processing modulations of amplitude or frequency. A1 is involved in most of the higher level processing that takes place in sound processing and is essential for recognizing when sound starts, stops, and changes pitch. In primates, three groups of areas have been identified in $\mathrm{A} 1$ : the core group, that stretches anterolateraly to posteromedi- 
aly along the lateral sulcus, with tonotopically organized areas, receiving most of thalamocortical input from ventral areas of MGC; the belt, situated medially and laterally to the core, receiving dorsal and medial areas of MGC inputs, and parabelt areas, receiving scattered dorsal and medial MGC fibers (Table 1) ${ }^{[5]}$.

Little is known about the interlaminar connections in the auditory cortex although they undoubtedly exist ${ }^{[5]}$. Each sound frequency is represented in a narrow strip along the surface of the cortex, with neurons at one end responding best to low frequencies and on the other to high frequencies, constituting a "frequency map". The purpose of this frequency (tonotopic) map is unknown, and likely reflects the fact that the cochlea is arranged according to sound frequency.
Secondary auditory cortex. The peripheral, secondary cortex (Broadmann's areas 42,22 ) is a unimodal homotypic area that surrounds the primary cortex and is located in the lateral portion of the superior temporal gyrus. It is involved in more subtle processing. There is a large degree of individual variation in the auditory cortex ${ }^{[6]}$.

Wernicke's area, important in comprehending speech, is just posterior to the primary auditory cortex ${ }^{[7]}$. The role of the right temporal lobe in pitch analysis is important for speech, since the pitch contributes to the "tone" of the voice, the prosody ${ }^{[8]}$. It is likely that certain characteristics of musical and language input are analyzed selectively by the two hemispheres. Music ability precedes spoken language as babies are sensitive to melodies and rhythms before they are born.

\begin{tabular}{l|l|l}
\hline Afferent auditory pathways & \multicolumn{1}{|c}{ Auditory cortex } & Efferent auditory pathways \\
\hline $\begin{array}{l}\text { Ascending thalamocortical } \\
\text { Projections from medial } \\
\text { Geniculate body }\end{array}$ & $\begin{array}{l}\text { Core, belt and parabelt } \\
\text { areas }\end{array}$ & $\begin{array}{l}\text { Descending corticothalamic } \\
\text { Projections to thalamus }\end{array}$ \\
Other subcortical structures & Brodmann's areas 41, 42, 22 & $\begin{array}{l}\text { Corticofugal projections to } \\
\text { Superior olivary cortex and } \\
\text { Cochlear nuclei }\end{array}$ \\
& & $\begin{array}{l}\text { Auditory interhemispheric } \\
\text { projections }\end{array}$ \\
& & $\begin{array}{l}\text { Projections to nonauditory } \\
\text { Cortex and limbic system }\end{array}$ \\
\hline \hline
\end{tabular}

Table 1. Auditory cortex, afferent and efferent pathways 
The pitch-selective neurons of the auditory cortex, located in a cortical region near the anterolateral border of the primary auditory cortex, are able to respond to pitch ${ }^{[9]}$. The auditory cortex is involved in tasks such as identifying and segregating auditory "objects" and identifying the location of a sound in space ${ }^{[4]}$. It is believed that auditory cortical interconnections follow the parcellation created by thalamocortical projections.

Auditory interhemispheric connections. The auditory interhemispheric projections far outweigh the proportions of similar connections in other sensory modalities, indicating that auditory cortical areas of both hemispheres represent quite integrated processing system $^{[5]}$.

Auditory output. Auditory cortical areas project onto various nonauditory frontal and parietal lobe areas, involved in other cognitive functions. Moreover, all descending pathways appear to be topographic in nature. Subcortical projections are back to thalamic nuclei within corticothalamic projections and also corticocollicular projections, terminating largely in the superior olivary complex and the cochlear nuclei ${ }^{[5]}$. There are other mostly understudied interconnections of the auditory cortex, presumed to have modulatory roles of the encoding of acoustic stimuli. Interconnections with the limbic system are very important, likely responsible for adding proper behavioural context to acoustic perception and memories ${ }^{[5]}$. Interfaces with other sensory systems probably integrate perception of space and object identity.

\section{Music and the brain}

"Music gives soul to the universe, wings to the mind, flight to the imagination, and charm and gaiety to life and to everything."

Plato

Pitch. Analysis of brain areas and pathways involved in cerebral processing of music is typically presented through analysis of particular elements of music (Table 2). Pitch is the fundamental element of music, related to sound frequency, with numerous studies designating a "pitch centre" in anterior auditory cortex ${ }^{[10]}$. PET studies indicate that the left core auditory cortex is specialized for temporal processing of the sound, while the right belt areas are dedicated to the spectral processing of pitch ${ }^{[1]}$. Excision of the right lateral Heschl's gyrus impairs the perception of changes in pitch, pitch direction, interval size, melodic contour, and complex tones. Undeniably secondary auditory association centres are important in complex pitch processin ${ }^{[11]}$. It has been suggested that the right temporal lobe has a special function in extracting pitch from sound, regardless of whether the sound is speech or music. 
Musicians with absolute pitch show a greater leftward asymmetry of the planum temporale than nonmusicians than musicians without absolute pitch, but due to structural reduction of the right planum temporale ${ }^{[1]}$. The right hemisphere is more active in musicians for detecting pitch changes in voice feedback, and the left hemisphere is more active during the processing of auditory feedback for vocal motor control and seems to involve specialized mechanisms that facilitate pitch processing in the absolute pitch $^{[12]}$. Musicians without absolute pitch show greater activity in the right inferior frontal cortex, important for working memory used to achieve better pitch, while musicians with absolute pitch exhibit greater activation in the left posterior dorsolateral frontal cortex, associated with conditional associations in memory ${ }^{[1]}$.

Timbr. Timbre or tone colour, is the psychoacoustic property of sound that permits us to differentiate between two different musical instruments playing at the same pitch; when each instrument of a symphony orchestra or the jazz band plays the same note, the quality of each sound is different, but the musician perceives each note as having the same pitch. Activity in both auditory cortices, with a degree of right lateralization, is responsible for the timbre ${ }^{[1]}$. If the right temporal lobe is lessoned, patients show a deficit in the discrimination of changes in timbre, compared to left-side lesions or intact brain.

Rhythm. Rhythm depends on activity of both hemispheres. Damage to the right temporal lobe impairs the perception of meter, while left-side lesions impair the discrimination of rhythmic patterns. Musical rhythms lead to activation in the left premotor and left parietal areas, as well as in the right anterior cerebellar lobe, while nonmusical rhythms lead to activation in the right prefrontal, right premotor and right parietal areas, as well as in the bilateral cerebellar posterior lobe ${ }^{[1]}$. Listening to musical rhythms recruits motor regions of the brain ${ }^{[13]}$.

There is a leftward dominance for temporal processing of rhythm, which implicates the recruitment of the language areas in the perception of the rhythm patterns. Both Broca's and Wernicke's areas are implied in rhythm processing, with increased activation in the left inferior frontal gyrus including Broca in the perception of rhythm. Additionally, musicians show increased activity in the left hemisphere in the passive perception of rhythm compared to nonmusicians, suggesting that hemispheric specialization for rhythm perception may be enhanced in musicians [1]. When words with descriptive, qualitative, structural or abstract similarities to particular musical excerpts were analyzed, they activated a response pattern similar to semantically related word or sentence pairs, evidencing that 
semantic interpretations of certain musical aspects might be shared ${ }^{[14]}$.

Musical structure. Musical structure comprising metric structure, tonality and counterpoint, depends on frontal lobe areas. Violations of tonality activates the inferior frontal regions, including Broca's area, and its homolog in the right hemisphere, as well as posterior temporal regions, including Wernicke's area. Rostromedial prefrontal cortex is a unique region that maintains a relative topographic map of tonality ${ }^{[15]}$. There is a hypothesis that the rostral medial prefrontal cortex is a node important for binding music with memories within a broader music-responsive network ${ }^{[16]}$.

Memory. Memory is imperative to the perception and production of music. Working memory for pitch requires the interaction of the right temporal and right frontal cortices. Recognition and identification of music as familiar demand several network activations, including bilateral auditory cortices, bilateral orbital, medial and inferior frontal regions, precuneus, angular gyrus and parahippocampal gyrus.

Imagery. The functional data showed substantial overlap during melody perception and imagery, including secondary auditory areas ${ }^{[17]}$. When imagery was compared with perception, an extended network including prefrontal cortex, supplementary motor area, intraparietal sulcus, and cerebellum showed increased activity, in line with the increased processing demands of imagery ${ }^{[17]}$. Functional connectivity of anterior right temporal cortex with frontal areas was increased during imagery compared with perception, indicating that these areas form an imagery-related network. The recognition task recruited overlapping areas, including the inferior frontal cortex associated with memory retrieval, as well as left middle temporal gyrus.

Emotional responses. Emotive responses to music are associated with limbic structures. Increased subjective emotional experience of music correlated with activation in ventral striatum, midbrain, amygdala, orbitofrontal cortex, and ventral medial prefrontal cortex according to the PET study ${ }^{[18]}$. Listening to the music eliciting strongly pleasant feelings led to increased activity observed in the subcallosal cingulate gyrus, prefrontal anterior cingulate, retrosplenial cortex, hippocampus, anterior insula, and nucleus accumbens in another PET study ${ }^{[19]}$.

On the other side, dissonant music correlated with activation in the right parahippocampal gyrus and right precuneus. In a review paper, Pauwels and co-workers ${ }^{[2]}$ summarized the results of PET and fMRI based studies of music effects on brain, reporting that large brain areas are engaged in music listening, including the limbic (amygdala and hippocampus) and paralimbic structures (orbitofrontal cortex, parahippo- 
campal gyrus, temporal poles). Interestingly, there is evidence that minor keys activate larger areas of the brain than the major keys ${ }^{[20]}$.

\section{Lateralization of music functions}

The left hemisphere is specialized for processing language-related sounds, whereas the right hemisphere processes music-related sounds ${ }^{[21]}$. The left hemisphere tends to predominate in the processing of sequential and discrete tonal components of music, as well as in musical tasks in professional musicians requiring more analytical processing ${ }^{[22,23]}$. The right hemisphere predominates in melody recognition and in melodic singing, but in musical amateurs. There appears to be no clear lateralization effect for rhythm perception, since it is processed in multiple areas in the brain $^{[23]}$. There is evidence that learning and retaining unfamiliar melodies involves the right hemisphere, while recognition of familiar melodies seems to depend more on the left hemisphere ${ }^{[23]}$.

According to Zatorre and Efron, speech and musical sounds exploit different acoustical cues: speech is highly dependent on rapidly changing broadband sounds, whereas tonal patterns of music tend to be slower, although small and precise changes in frequency are important ${ }^{[8]}$. The auditory cortices in the two hemispheres are therefore specialized in a way that temporal reso- lution is better in the left and spectral resolution in the right auditory areas; it is possible that because an acoustical system cannot simultaneously analyse both temporal and spectral aspects of sound, the cortical asymmetries related to acoustical processing may have developed as a solution to the need to optimize the processing of acoustical stimuli $^{[21]}$.

Music training can alter lateralization in the sense that in musicians the left hemisphere predominates in melody recognition, tone discrimination and musical judgments ${ }^{[24,25]}$. Integration of functions of both hemispheres is needed for musical appreciation and performance ${ }^{[26]}$. It is interesting that in the guitar and violin family the right hand performs those aspects of music that are mediated predominantly by the right hemisphere, such as expression and tonality, while the left hand interprets the linear sequence of notes best decoded by the left hemisphere ${ }^{[22]}$. Patients with right temporal lobectomies and other temporal lobe lesions exhibit memory deficits that involve designs, faces, melodies and spatial formats ${ }^{[22]}$. 


\begin{tabular}{|c|c|}
\hline Music element & Brain areas involved \\
\hline Pitch & Auditory cortex and secondary auditory association areas \\
\hline Timbre & Auditory cortex with right lateralization \\
\hline Rhythm & $\begin{array}{l}\text { Left auditory cortex for discrimination of rhythmic } \\
\text { patterns, right auditory cortex for perception of meter }\end{array}$ \\
\hline Musical structure & $\begin{array}{l}\text { Left and right inferior frontal regions, posterior temporal } \\
\text { regions, rostromedial prefrontal cortex }\end{array}$ \\
\hline \multirow[t]{2}{*}{ Musical memory } & $\begin{array}{l}\text { Bilateral auditory cortices, bilateral orbital, medial and } \\
\text { inferior frontal regions, precuneus, angular gyrus and }\end{array}$ \\
\hline & parahippocampal gyrus \\
\hline Musical imagery & $\begin{array}{l}\text { Secondary auditory areas, prefrontal cortex, } \\
\text { supplementary motor area, intraparietal sulcus and } \\
\text { cerebellum, anterior right temporal cortex }\end{array}$ \\
\hline Emotion & $\begin{array}{l}\text { Limbic system, ventral striatum, midbrain, amygdala, } \\
\text { orbitofrontal cortex, and ventral medial prefrontal cortex }\end{array}$ \\
\hline
\end{tabular}

Table 2. Representation of different elements of music in the brain

\section{Music cognition models}

Music cognition models have been proposed, explaining processes occurring in our brain simultaneously or in quick succession while listening to music. A series of cognitive activities are needed, such as recognition of melody, musical memory, recognition of lyrics, emotional state, etc. ${ }^{[23]}$. According to Peretz and Coltheart a functional model, melodic system, located in the right superior temporal gyrus but depending on its connection with frontal lobes, is responsible for processing all melody information, and discriminates between tones and intervals or differences between tones ${ }^{[27]}$.

There is also the temporal system, working with the previous one, but responsible for rhythm and musical meter, with the melody system being "how" and the temporal system being "when" in perception of music ${ }^{[23]}$. Both networks 
send information to the musical lexicon, which creates the musical repertoire, perceptual representation of all musical pieces and works we were exposed to in our lives, and also depending on musical memory ${ }^{[23]}$.

\section{Environment or genes?}

Recent advances in genetic research implicated several loci on chromosome 4 in singing and music perception, and certain loci on chromosome 8q in absolute pitch and music perception ${ }^{[28]}$. The gene AVPR1A on chromosome 12q has been associated with music perception, music memory, and music listening, whereas SLC6A4 on chromosome 17q with music memory and choir participation ${ }^{[29]}$. Researchers generally agree that both genetic and environmental factors contribute to the broader realization of music ability, with the degree of music aptitude varying.

\section{Brain lesions and music - amusias}

By definition of the syndrome, patients with amusia have intact auditory system and other cognitive functions ${ }^{[30]}$. Loss of musical abilities is not related to the loss of verbal functions, as is obvious in patients with aphasia and preserved musical abilities.

Types of amusia. Benton identified several different types of amusias, including receptive and expressive amusia
${ }^{[31]}$. According to current clinical classifications, motor amusia refers to the loss of ability to sing, whistle, or hum; sensory amusia (tone deafness), the loss of ability to discriminate pitches; musical amnesia, the loss of ability to recognize known pieces of music; musical apraxia or instrumental amusia, the loss of ability to play an instrument; musical agraphia, the inability to write music; and musical alexia, the inability to read musical scores ${ }^{[31]}$. Bimanual instrument apraxia is an inability to use both hands to play a musical instrument, reported in left hemisphere lesions that spare motor functions ${ }^{[31]}$. Patients with amusia report perceiving music as grating, explosive, strident ${ }^{[23]}$.

Incidence. The incidence of acquired amusia is not known but the phenomenon is considered rare ${ }^{[23]}$. However, it is likely that amusia is more frequent but under investigated and underreported $^{[23]}$. There is a great difficulty in classification of amusia, due to different approaches used in the literature, and clinical and pathological description being based on isolated reported cases.

Temporal lobe lesions. One of the principal symptoms of the temporal lobe dysfunction, particularly superior temporal gyrus on the right, are disorders of music perception. This is a music-specific agnosia, due to brain injury in acquired amusia cases. In patients with temporal lobectomies, injury affecting superior temporal gyrus impairs 
various aspects of processing necessary for discriminating music ${ }^{[32]}$. Interestingly, rhythm discrimination was most affected by right posterior superior temporal gyrus damage, whereas distinguishing meter (distinguishing a waltz and a march) was more affected by anterior damage to either temporal lobe ${ }^{[32]}$.

\section{Congenital amusia}

In congenital amusia, people are tone deaf from birth and no musical training make any difference. According to some studies, congenital amusia seems to be present in $5 \%$ of the population ${ }^{[23]}$. The phenomenon is attributed to abnormality in neural network for music, associated with structural variations in the frontal and temporal lobes.

Patients with congenital amusia present less white matter than healthy subjects, especially in Broadmann's area $47 / 44$ of the right inferior frontal gyrus, which is active in healthy subjects during tasks involving musical memo$\mathrm{ry}^{[33,34]}$. It is likely that these areas participate in pitch processing by means of frontotemporal connections with the right auditory cortex, but are underdeveloped in amusic patients ${ }^{[23]}$. Other research indicated increase of grey matter in the same region, which could be secondary phenomenon or sign of impairment of neuronal migration ${ }^{[3]}$.

\section{Etiology od acquired amusia}

Etiology of acquired amusia is comprising many diseases and conditions leading to brain injury, including traumatic brain injury, ischemic or hemorrhagic stroke, neoplasms, iatrogenic, epilepsy-related, infections, degenerative or idiopathic ${ }^{[23,35]}$. In spite of numerous publications, recent systematic review pointed to heterogeneity in methodology and small numbers of participants in so far published research ${ }^{[35]}$.

\section{Musical functions and nommusical cognition}

Recent research showed that amusic patients score lower on test of memory, attention and cognitive flexibility compared to non-amusic subjects [36]. Interestingly, there is also evidence that intonation of speech - prosody, is not impaired in patients with amusia, since two distinct processes are involved, one for singing intonation and one for speaking intonation. However, the nonverbal aspects of speech are important for communication as evidenced when listening to the often flat or misplaced intonations of patients with right hemisphere damage. Studies indicated that musical perception depends on the same cognitive processes needed for spatial processing, with cases of amusic patients showing signs of spatial impairment ${ }^{[37]}$. 


\section{Testing for amusia}

Diagnostic evaluation of amusia mainly relies on testing of musical perception and musical memory. The Montreal Battery of Evaluation of Amusia (MBEA) designed in 1987 is one of the most widely used tests ${ }^{[33]}$.

Bedside amusia assessment can be easily improvised, with an examiner whistling or humming several simple and familiar melodies to the examinee ${ }^{[22] .}$ Additionally, a pitch pipe can be used, with patients responding which of the two sounds is higher or whether two sounds are the same of different.

Examples of rhythm pattern can be presented to the patient, with a task to discriminate similar and different sets or patterns or to mimic them with a pencil on a table top ${ }^{[22]}$. There are also other formalised batteries for systematic examination of musical functions ${ }^{[22]}$.

\section{CONCLUSION}

Enjoying, listening, analysis and creating music requires activity and cooperation between numerous brain areas, which makes it an attractive topic for cognitive neuroscientists. Effects of music training on human brain are fascinating examples of brain plasticity and may be used for research and rehabilitation purposes. Acquired disturbances of these processes may be rare and of little functional importance for patients, but considering brain areas involved in music processing and range of underlying diseases involved, these disorders are likely underreported in everyday clinical practice. 


\section{MUZIKA KOD ZDRAVOG I OBOLELOG MOZGA}

\section{Aleksandra M. Pavlović 1,2 Dragan M. Pavlović $3,4,5$}

\section{Medicinski fakultet, Univerzitet u} Beogradu, Beograd, Srbija

2. Klinika za neurologiju, Klinički centar Srbije, Beograd, Srbija

3. Fakultet za specijalnu edukaciju i rehabilitaciju, Univerzitet $u$ Beogradu, Beograd, Srbija

4. Odeljenje za psihologiju, Filozofski fakultet, Univerzitet u Beogradu, Beograd, Srbija

5. Poliklinika Antamedica, Beograd, Srbija

\section{UDK: 616.895.8-085}

\section{Napomena:}

Rad je delom finansiran sredstvima iz projekata broj 175033 i 175022 Ministarstva za nauku i tehnološki razvoj Republike Srbije.

\section{Kratak sadržaj}

Umetnost i kreativnost potiču iz mozga i zavise od njegovog normalnog funkcionisanja. Muzika je multifacetni fenomen koji postoji kao univerzalno nasleđe $u$ svim ljudskim društvima i kroz čitavu ljudsku istoriju. Postoje mnogobrojni moždani mehanizmi uključeni u kognitivnu obradu muzike, uključujući slušanje muzike, izvođenje, pisanje, čitanje, kao i muzičku estetiku i muzičke emocije. Muzika se odnosi na mnoge funkcije mozga, uključujući percepciju, motoriku, kogniciju, emocije, učenje i pamćenje. Različiti regioni mozga su povezani sa obradom $i$ proizvodnjom muzike, uključujući prave prednje i zadnje superiorne temporalne režnje, desno inferiorni frontalni korteks, desno prefrontalni, bilateralni premotor i bilateralni parietalni prostori, desni anteriorni cerebelarni režanj, jezičke površine, limbičke strukture. U obolelom mozgu, nakon traume mozga, opisani su poremećaji u percepciji ili produkciji muzike, iako se smatraju retkim. Amuzija ili specifična 
muzička agnozija, narušena percepcija muzike ili njenih komponenti obično se povezuje sa lezijama temporalnog režnja i pretežno se javlja kod oštećenja desne polovine mozga. Etiologija stečene amusije obuhvata mnoge bolesti i stanja koji dovode do lezija mozga, uključujući traumatske povrede, ishemijski ili hemoragični moždani udar, neoplazme, jatrogena stanja, epilepsije, infekcije i degenerativne bolesti. Postoje i slučajevi kongenitalne amuzije, u vezi poremećaja neuronskih mreža za muziku, povezanih sa strukturnim varijacijama u frontalnom i temporalnom režnju.

\section{Ključne reči:}

muzička gnozija, amuzija, neurologija ponašanja, mozak i muzika, trauma mozga

\section{REFERENCES / REFERENCE}

1. Donnelly PJ, Limb CJ. Music. In: Squire LR, editor. Encyclopedia of Neuroscience. Academic Press, Oxford; 2009.

2. Pauwels EK, Volterrani D, Mariani G, Kostkiewics M. Mozart, music and medicine. Med Princ Pract 2014; 23:403-412.

3. Schlaug G. Part VI introduction: listening to and making music facilitates brain recovery processes. Ann N Y Acad Sci 2009; 1169:372-373.

4. Kreutzer JS, DeLuca J, Caplan B. Encyclopedia of Clinical Neuropsychology. New York, NY: Springer; 2011.

5. Barbour D. Auditory Cortex Structure and Circuity. In: Squire LR, editor. Encyclopedia of Neuroscience. Oxford: Academic Press; 2009.

6. Beament J. How we hear music: the relationship between music and the hearing mechanis. Woodbridge, Suffolk: Boydell Press; 2001.

7. Purves $D$, Augustine GJ, Fitzpatrick $D$, Katz LC, LaMantia A-S, O McNamara J, Williams SM. Neuroscience. 2nd ed. Sunderland, MA: Sinauer Associates; 2001.

8. Zatorre RJ, Belin P, Penhume VB. Structure and function of auditory cortex: Music and speech. Trend Cogn Sci 2002; 6:37-46.

9. Bendor $D$, Wang $X$. The neuronal representation of pitch in primate auditory cortex. Nature 2005; 436:1161-1165. 
10. Norman-Haignere S, Kanwisher N, McDermott JH. Cortical pitch regions in humans respond primarily to resolved harmonics and are located in specific tonotopic regions of anterior auditory cortex. J Neurosci 2013; 33:19451-19469.

11. Javad F, Warren JD, Micallef C, Thornton JS, Golay X, Yousry T, Mancini L. Auditory tracts identified with combined $\mathrm{FMRI}$ and diffusion tractography. Neuroimage 2014; 84:562-574.

12. Behroozmand R, Ibrahim N, Korzyukov O, Robin DA, Larson $C R$. Left-hemisphere activation is associated with enhanced vocal pitch error detection in musicians with absolute pitch. Brain Cogn 2014; 84:97-108.

13. Chen JL, Penhune VB, Zatorre RJ. Listening to musical rhythms recruits motor regions of the brain. Cereb Cortex 2008; 18:2844-2854.

14. Peretz I. Radeau M, Arguin M. Twoway interactions between music and language: evidence from priming recognition of tune and lyrics in familiar songs. Mem Cogn 2004; 32:142-152.

15. Janata P, Birk JL, Van Horn JD, Leman M, Tillmann B, Bharucha JJ. The cortical topography of tonal structures underlying Western music. Science 2002; 298:2167-2170.

16. Janata P. Brain networks that track musical structure. Ann N Y Acad Sci 2005; 1060:111-124.

17. Herholz SC, Halpern AR, Zatorre RJ.
Neuronal correlates of perception, imagery, and memory for familiar tunes. J Cogn Neurosci 2012; 24:1382-1397.

18. Blood AJ, Zatorre RJ. Intensely pleasurable responses to music correlate with activity in brain regions implicated in reward and emotion. Proc Natl Acad Sci U S A 2001; 98:11818-11823.

19. Brown S, Martinez MJ, Parsons LM. Passive music listening spontaneously engages limbic and paralimbic systems. Neuroreport 2014; 15:2033-2037.

20. Nemoto I, Fujimaki T, Wang LQ. fMRI measurement of brain activities to major and minor chords and cadence sequences. Conf Proc IEEE. Eng Med Biol Soc 2010; 5640-5643.

21. Kolb B, Whishaw IQ. Fundamentals of Human Neuropsychology. 5th ed. New York, NY: Worth Publishers; 2003.

22. Lezak MD, Howieson DB, Loring DW. Neuropsychological assessment. 4th ed. New York, NY: Oxford University Press; 2004.

23. García-Casares N, Berthier Torres ML, Froudist Walsh S, González-Santos P. Model of music cognition and amusia. Neurologia 2013; 28:179-186.

24. Shanon B. Classification of musical information presented to the right and left ear. Cortex 1981; 17:583-596.

25. Shanon B. Asymmetries in musical aesthetic judgements. Cortex 1984; 20:567-573.

26. Bauer RM, Demetry JA. Agnosia. In: Heilman KM. Valenstein E, editors. 
Clinical Neuropshychology. New York: Oxford University Press; 2003.

27. Zatorre RJ. Musical perception and cerebral function: a critical review. Music Percept 1984; 2:196-221.

28. Tan YT, McPherson GE, Peretz I, Berkovic SF, Wilson SJ. The genetic basis of music ability. Front Psychol 2014; 5:658.

29. Ukkola-Vuoti L, Oikkonen J, Onkamo P, Karma K, Raijas P, Järvelä I. Association of the arginine vasopressin receptor 1A (AVPR1A) haplotypes with listening to music. J Hum Genet 2011; 56:324-329.

30. Alossa N, Castelli L. Amusia and musical functioning. Eur Neurol 2009;61:269-277.

31. Benton AL. The amusias. In: Critchley $M$, Henson AR, editors. Music and the brain. London, UK: William Heinemann Medical Books Ltd; 1977.

32. Liegeois-Chauvel C, Peretz I, Babai M, Laguitton V, Chauvel P. Contribution of different cortical areas in the temporal lobes to music processing. Brain 1998; 121:1853-1867.

33. Hyde KL, Zatorre RJ, Griffiths TD, Lerch JP, Peretz I. Morphometry of the amusic brain: a two-site study. Brain 2006; 129:2562-2570.

34. Hyde KL, Zatorre RJ, Peretz I. Functional MRI evidence of an abnormal neural network for pitch processing in congenital amusia. Cereb Cortex 2011; 21:292-299.

35. Casey DA. Aetiology of auditory dysfunction in amusia: a systematic review. Int Arch Med 2013; 6:16.
36. Särkämö T, Tervaniemi M, Soinila $S$, Autti T, Silvennoinen HM, Laine M, Hietanen M, Pihko E. Auditory and cognitive deficits associated with acquired amusia after stroke: a magnetoencephalography and neuropsychological follow-up study. PloS ONE 2010; 25:e15157.

37. Douglas KM, Bilkey DK. Amusia is associated with deficits in spatial processing. Nat Neurosci 2007; 10:915-921.

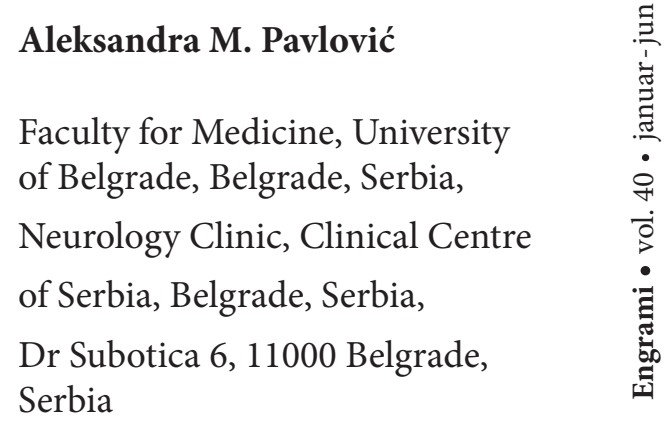

aleksandra3003@yahoo.com 